\title{
Manifesting the grace of God to those with HIV or AIDS
}

\begin{tabular}{|c|c|}
\hline \multicolumn{2}{|l|}{$\begin{array}{l}\text { Author: } \\
\text { Arnau van Wyn }\end{array}$} \\
\hline \multicolumn{2}{|c|}{$\begin{array}{l}{ }^{1} \text { Swaziland Reformed Church, } \\
\text { Shiselweni, Swaziland }\end{array}$} \\
\hline \multicolumn{2}{|c|}{$\begin{array}{l}{ }^{2} \text { Department of Science of } \\
\text { Religion and Missiology, } \\
\text { University of Pretoria, } \\
\text { South Africa }\end{array}$} \\
\hline \multicolumn{2}{|c|}{$\begin{array}{l}\text { Correspondence to: } \\
\text { Arnau van Wyngaard }\end{array}$} \\
\hline \multicolumn{2}{|c|}{$\begin{array}{l}\text { Email: } \\
\text { wyngaard@lando.co.za }\end{array}$} \\
\hline \multicolumn{2}{|c|}{$\begin{array}{l}\text { Postal address: } \\
\text { PO Box } 886 \text {, Piet Retief 2380, } \\
\text { South Africa }\end{array}$} \\
\hline \multicolumn{2}{|c|}{$\begin{array}{l}\text { Dates: } \\
\text { Received: } 20 \text { Aug. } 2012 \\
\text { Accepted: } 18 \text { Sept. } 2013 \\
\text { Published: } 16 \text { Apr. } 2014\end{array}$} \\
\hline \multicolumn{2}{|c|}{$\begin{array}{l}\text { How to cite this article: } \\
\text { Van Wyngaard, A., 2014, } \\
\text { 'Manifesting the grace of } \\
\text { God to those with HIV or } \\
\text { AIDS', Verbum et Ecclesia } \\
35(1) \text {, Art. \#780, } 7 \text { pages. } \\
\text { http://dx.doi.org/10.4102/ } \\
\text { ve.v35i1.780 }\end{array}$} \\
\hline \multicolumn{2}{|c|}{$\begin{array}{l}\text { Note: } \\
\text { Dr Arnau van Wyngaard } \\
\text { is a Research Associate of } \\
\text { the Department of Science } \\
\text { of Religion and Missiology, } \\
\text { University of Pretoria. }\end{array}$} \\
\hline \multicolumn{2}{|c|}{$\begin{array}{l}\text { Copyright: } \\
\text { (C) 2014. The Authors. } \\
\text { Licensee: AOSIS } \\
\text { OpenJournals. This wc } \\
\text { is licensed under the } \\
\text { Creative Commons } \\
\text { Attribution License. }\end{array}$} \\
\hline \multicolumn{2}{|l|}{ Read online: } \\
\hline 口ifida & $\begin{array}{l}\text { Scan this QR } \\
\text { code with your } \\
\text { smart phone or } \\
\text { mobile device } \\
\text { to read online. }\end{array}$ \\
\hline
\end{tabular}

'The most terrible poverty is loneliness and feeling unloved' (Mother Teresa). Swaziland is in the unenviable position of having the highest HIV infection rate in the world, with an adult prevalence rate of $42 \%$. This is a national crisis which, in the Swaziland context, has led to feelings of severe hopelessness and rejection and which needs to be addressed through a multidisciplinary approach. The church is in the unique position to demonstrate the love and grace of God in the midst of this pandemic. A small congregation of the Swaziland Reformed Church situated in the southern Shiselweni district of the country decided to take up this challenge. This article showed what the effects could be when the church becomes a vessel of love and grace within the community.

\section{Introduction}

Given the choice, most people would prefer to evade the problem of human immunodeficiency virus (HIV) and acquired immunodeficiency syndrome (AIDS). Who would choose, of their own free will, to spend their lives serving those suffering from the effects of the worst pandemic in world history? The challenge becomes even more difficult when people ascribe the existence of this disease to the sinful choices people make (Kidd \& Clay 2003:2). When people suffer 'innocently', the world reaches out in a variety of ways to help them. But when it is perceived that people have brought their suffering upon themselves, the usual response is to ignore their suffering. The oft-quoted words of Gideon Byamugisha (in Van Wyngaard 2006), an Anglican priest from Uganda who himself is HIV-positive, are a case in point:

It is now common knowledge that in HIV/AIDS, it is not the condition itself that hurts most (because many other diseases and conditions lead to serious suffering and death), but the stigma and the possibility of rejection and discrimination, misunderstanding and loss of trust that HIV positive people have to deal with. (pp. 281-282)

In research conducted in Trinidad, it was found that the HIV and AIDS pandemic in the Caribbean is fuelled by stigma and discrimination, 'which are the most significant determinants of HIV infection and death from AIDS related complications' (Genrich \& Brader 2005:2). Stigma and discrimination rob people of the freedom to have themselves tested and to receive treatment, both formally and informally, such as through home-based caregiver groups.

Even the church, in its compassion, indirectly continues to stigmatise those who are HIV-positive, as illustrated in the following account:

At the World AIDS Day celebration in the Roman Catholic Cathedral in Bujumbura in 1995, the priest said, in the course of his sermon, 'We must have compassion for people with AIDS because they have sinned and because they are suffering for it now'. At that point something propelled Jeanne Gapiya to rise from her pew and walk up to the front of the church. 'I have HIV', she declared, 'and I am a faithful wife. Who are you to say that I have sinned, or that you have not? We are all sinners, which is just as well, because it is for us that Jesus came'. (Brown \& Hendriks 2004:27)

\section{Objective of this research}

As it is presumed that many people contract HIV outside of wedlock, a double burden afflicts people living with HIV and AIDS: not only does HIV infection suggest extramarital sex, or worse, promiscuity, but because HIV infection is seen as something immoral, it is often viewed as a punishment or curse from God (Campbell, Skovdal \& Gibbs 2010; Hermsen \& Ten Have 2004:355; Hlongwana \& Mkhize 2007:557).

For many, even the church is experienced as a place of condemnation, a place where they need to hide their pain and uncertainty, rather than a place where they experience the love and the grace of God. The Swiss doctor, Paul Tournier, illustrates this through the words of the author, Philip Yancey (1997): 
Tournier tells of patients who come to him: a man harboring guilt over an old sin, a woman who cannot put out of her mind an abortion that took place ten years before. What the patients truly seek, says Tournier, is grace. Yet in some churches they encounter shame, the threat of punishment, and a sense of judgment. In short, when they look in the church for grace, they often find ungrace. (p. 31)

If it is true that stigma and discrimination are two significant reasons why the AIDS pandemic cannot be contained (Deacon, Stephney \& Prosalendis 2005:viii-ix), then the church, as body of Christ, has the responsibility to create an environment where people will experience love, grace and understanding, rather than stigmatisation and discrimination. In the words of Moyo and Banda (in Van Klinken 2008):

The Church, by its very nature as a body of Christ, should seek to call its members to become healing communities. The Church is an affective healing witness towards those infected and affected. The experience of love, care, acceptance and support within the community where God's love is manifest can be a powerful healing force. (p. 323)

Churches and faith-based organisations are often perceived to have a condemning attitude (Joint United Nations Programme on HIV and AIDS [UNAIDS] 2005:22) and HIV and AIDS stigmatisation in Africa has been linked to 'barriers to testing, treatment, care and adherence; on quality of life; and on social responses to HIV / AIDS' (Deacon et al. 2005:viii). The objective of this research was to determine what the experiences are of people who are normally stigmatised and discriminated against, when the church starts demonstrating unconditional love to them. Shiselweni Reformed HomeBased Care (SHBC) has a reputation for reaching out to people in need and supporting them, regardless of who they are or what the cause was for their present circumstances. As stated in their mission statement, the organisation wants to reach out in love to those in need, comforting and supporting them by all means available.

\section{The biblical concept of 'grace'}

In the Old Testament, the word most often used for 'grace' - חָזָ (hānan $)$ - '... denotes the stronger coming to the help of the weaker who stands in need of help by reason of his circumstances or natural weakness' (Esser 1971:116). Although the New Testament uses the term $\chi \alpha$ ó mostly to indicate the undeserved act of salvation through Jesus Christ, in the life and teachings of Jesus we see God's gracious heart for the weak, the poor, the hopeless and the lost. According to Louw and Nida (1988), xópıs has the meaning of showing kindness to someone, with the implication of graciousness on the part of the one showing such kindness:

It is important to note that kindness in English indicates an activity in which an individual is kind to someone; it is essentially an event involving a particular quality. The same is true of $\chi$ ópls in Ac 15.40, for this is not a mere gracious disposition, but an expectation of the Lord's showing kindness. (pp. 749-750)

This viewpoint is confirmed by McDonald (1980) when he writes:
He sought out the sinful. This is the new note of the Gospel. Judaism taught that God was ready to be gracious, but was inclined to leave the first step with the sinner. The distinctive thing with Jesus was His taking of the deliberate initiative on God's behalf. That is grace! (p. 800)

It is exactly this attitude that Brown and Hendriks (2004:21) argue for in the church. The theoretical teachings about God's grace need to become practical in the life of the individual who has become marginalised and afraid. This would mean that the church needs to understand the anguish of humans as they look upon God to be gracious to them. Furthermore, the church needs to experience the depths of despair in which the person with AIDS is caught and be for them what God wants to be for them. The church needs to become HIVpositive (Byamugisha, Raja \& Chitando 2012).

\section{Research methodology}

Data used for this article are derived from a qualitative study that was designed to explore SHBC client experiences. ${ }^{1}$ From 17-28 January 2011, face-to-face semi-structured openended interviews were conducted with SHBC clients $(N=79)$ to better understand their experiences of SHBC care and support. ${ }^{2}$ Out of the total 27 communities in which SHBC provided care services at that time, 11 were purposively sampled as sites of investigation based on the duration of SHBC's operations in the community, focusing on care groups established from 2007 to 2009 , as well as ranging from communities with a low caregiver-client ratio (1:2), to those with a high caregiver-client ratio (1:5.7).

Purposive sampling criteria were that the individual had been diagnosed with HIV and was a client of SHBC at the time of the interview. Participants were notified of the study in advance by their care supporters and informed consent secured when the questionnaire was conducted in person.

The research questions were operationalised in terms of the following variables: clients' critical needs, social networks for meeting those needs, perceptions of caregiver practices, HIV and AIDS communication with caregivers, family reactions to the caregiver, personal religiosity and the significance of caregivers' Christian affiliation. Research procedures were approved before research commenced by Baruch College's Human Research Protections Program, City University of New York (USA).

\section{Data analysis}

Using the transcriptions made of the interviews, specific thematic categories were identified as the open-ended responses to the interviews were analysed. Of the 46 questions used during the interviews, 9 were specifically relevant for research on the effectiveness of manifesting grace to people living with HIV and AIDS. These questions were the following:

1.See Root and Van Wyngaard (2011), for an in-depth discussion of the study methodology.

2.See Root (2011), for an in-depth discussion of the methodology followed. 
- Do you feel comfortable asking family members for help?

- What did you think when the care supporter first came and introduced themselves to you?

- What is the most important thing they do for you?

- Would you say your health has changed since the care supporter started visiting?

- Is it comfortable talking about HIV and AIDS with the care supporters?

- Have the care supporter and you ever talked about antiretroviral therapy (ART)?

- What do you feel would happen if the SHBC care supporter had never come to your home, or stopped coming to visit?

- Can you tell me, is it important to you that a care supporter be a Christian, or does it not matter?

- What do you feel would happen if the care supporter could no longer visit you?

The responses to the above questions were further analysed to detect trends in the answers given.

\section{Coming face to face with the grace of God}

In 2005, the present CEO of SHBC, Arnau van Wyngaard, was invited to Utrecht in the Netherlands to present three workshops on the role of the church in the fight against AIDS at the General Assembly of the Reformed Ecumenical Council. ${ }^{3}$ During the course of the assembly, all delegates were invited to attend church at The Scots International Church in Rotterdam one Sunday morning. In spite of the wealth of the majority of the population in Rotterdam, this city, which hosts the busiest harbour in the world, has a large number of people normally regarded as outcasts, such as drug addicts, alcoholics and prostitutes. This congregation has the vision to reach out to these outcasts and to serve the poor and the destitute of the city. Later, during lunch, the practical implications of this vision were clearly demonstrated:

I noticed a man entering the dining room who displayed clear signs of mental retardation. With slight discomfort I kept an eye on him, wondering how the local church leaders were going to handle the situation and expecting them to guide this man out of the dining room, at most with a sandwich in his hand. And then, instead of doing what I expected (and what I perhaps would have done myself in similar conditions), this man was approached with warmth and sensitivity and invited to share our lunch! And it was at that moment that I knew that, had Jesus been on earth that day and at that place as a human Person, He would have done exactly the same. While sitting at my table I inwardly cried out to God and said that I wanted my own congregation in Swaziland to be like this: The people in Swaziland had to experience Jesus in the way that this man had experienced Him that day in Rotterdam. (Van Wyngaard 2008a:n.p.)

\section{The effects of HIV and AIDS on Swaziland}

Swaziland is a small, landlocked country bordered by South Africa to the north, west and south, and by Mozambique to of HIV/AIDS' (Van Wyngaard 2006a). the east and is currently the country with the highest HIV infection rate in the world. Whilst the adult prevalence rate in Swaziland is $42 \%$, the prevalence rate amongst women aged 25-29 years is estimated to be above $49 \%$ and $25 \%$ of women older than 40 years of age are HIV-positive (Ministry of Health 2009). UNAIDS (2010:136) reports that 33\% of Swazi women experienced some form of sexual violence before reaching 18 years of age. As Swaziland's population gradually decreases, so the number of orphans is increasing at an alarming rate. More than $10 \%$ of the entire population is categorised as 'orphaned or vulnerable children' and there is no indication that this trend will be reversed in the near future. In the words of Whiteside (in Whiteside \& Whalley 2007):

In Swaziland, HIV / AIDS is creating a chronic emergency that is permanently altering development. This demonstrates a 'new' disaster that exceeds emergency thresholds and requires a new style of holistic response. (p. vii)

Swaziland consists of four regions: Hhohho, Manzini, Lubombo and Shiselweni. The latter, situated in the southern part of Swaziland, is the poorest and also the most vulnerable region in Swaziland. In 2000, the HIV prevalence rate in Shiselweni was the lowest in the country, but by 2006 this region's HIV statistics escalated to top the chart (Whiteside \& Whalley 2007:5). It is primarily a rural area where the population is dependent upon subsistence farming for survival. Young people tend to migrate to the northern areas of Swaziland after school, especially to Mbabane, Manzini or Matsapha - Swaziland's industrial zone - where they have increased employment opportunities.

In the Dwaleni and Matsanjeni areas, situated approximately $10 \mathrm{~km}$ and $75 \mathrm{~km}$, respectively, from Nhlangano, the capital town of the Shiselweni region, a homestead-to-homestead survey was conducted to determine the needs of the people within the areas. ${ }^{4}$ Some of the distressing statistics emerging from this survey indicated that in almost $50 \%$ of the households surveyed the husband or father had died. In $62 \%$ of the households, one or more persons had died within the previous 12 months and $15 \%$ of the 567 individuals within these households had been hospitalised during the same period.

Funerals have become part of the lifestyle of the population in these rural areas. Whilst taking part in a discussion with a group of people at Dwaleni, the question was asked whether many funerals were held. One of the Swazi members answered:

This morning we buried two people. Tomorrow morning we will bury two more people. For next Saturday two funerals have already been arranged and another two have been arranged for next Sunday. And every weekend it is the same. (Van Wyngaard 2006b:1100)

This is the state of matters in an area measuring only a few square kilometres. The effect of these traumatic experiences

4.The survey was conducted with the help of a team of mission students from Operation Mobilisation, making use of a printed questionnaire. 
on the population and especially on the children can hardly be imagined.

\section{Becoming Christ for the community}

It is within these circumstances that the Dwaleni congregation of the Swaziland Reformed Church in 2005 resolved that they could no longer remain spectators as people across the area were 'dying like flies', as the colloquial expression went. Still, the answer to addressing the problem in a tangible way evaded the congregation for a long time. Then, after several weeks of exploring the topic of God's grace and God's caring for people in desperate situations, church members felt challenged to respond to what they had heard God saying to them. The breakthrough came when they indicated that the church should become involved in the community, bringing comfort and hope into the lives of people with HIV or AIDS (Van Wyngaard 2006b:1095-1109). In a community where people are forced to focus on survival, it was remarkable that people now wished to devote their lives to serving others.

The next step was to decide what the most appropriate way would be to render assistance to community members. Church members felt that there were essentially three ways in which people in an AIDS-ridden community could be helped: through prevention programmes, education and caring. The church has a poor track record when it comes to AIDS prevention, often experienced as being moralistic whilst maintaining a conservative and stigmatising viewpoint of sexuality (Campbell et al. 2010). On the other hand, the church has a lot which counts in its favour when education becomes its main focus. A building is available, church leaders are accustomed to addressing audiences and because they are also familiar with the role of teaching, it would be fairly easy for them to assume the role of HIV and AIDS educators.

Likewise, the church is ideally suited to initiate caring within communities (Campbell et al. 2010). Jesus set the example in this regard and the early church followed suit. The pagan emperor, Julian the Apostate (361 AD - 363 AD), was so amazed with the sheer benevolence and excellence of Christian philanthropy that he was compelled to admit in wonder their superiority over paganism in matters of charity: 'These godless Galileans (i.e. Christians) feed not only their own poor but ours: our poor lack our care.' He then observes, 'This godlessness (i.e. the church) is mainly furthered by its philanthropy towards strangers and its careful attention to the bestowal of the dead.' Eventually this pagan emperor could only write in amazement, '... how they love one another! ... Look how they are prepared to die for one another' (Themistocles 1988:n.p.).

Challenged by this attitude, the church members at Dwaleni resolved to involve themselves with the plight of the people in the community, regardless of faith, gender or, importantly, the cause of their HIV status. In order to find the most effective way in which the rural community of Dwaleni could be served, it was decided to organise an AIDS conference. Different speakers were invited to address the community members, each emphasising a different aspect of caring for people living with HIV or AIDS. However, it soon became clear that one organisation invited to speak, Project Support Association (PSA), gripped the hearts of those who attended. PSA focuses on training home-based care supporters and during the time given for discussion the entire group was unanimous that this was what they wanted to do.

Hospitals in Swaziland are totally inadequate for the needs of the population in the present circumstances. Swaziland has approximately 2000 hospital beds for a population of slightly more than 1 million, of which $90 \%$ are located in towns despite the rural bias of the population. In 2006, over $40 \%$ of admissions at the largest public hospital in Swaziland were as a result of conditions often associated with HIV or AIDS, for example tuberculosis, non-infective gastroenteritis and pneumonia. Furthermore, between $50 \%$ and $75 \%$ of all outpatient cases have HIV-related or AIDS-related complaints (Whiteside \& Whalley 2007:8). The reality is that terminally ill people are hospitalised until they are stabilised and then often sent home where they die. Whilst in hospital, most patients ask family members or friends to remain with them in order to feed and wash them, as the understaffed hospitals cannot provide in these basic needs.

When these patients return to their own homesteads, family members need to care for them, despite their lack of knowledge or experience in taking proper care of the sick. What church members at Dwaleni envisioned was that they, with proper training, could fulfil this basic role of caregiver. The vision they had was ' $[t]$ o become the hands and the feet of Christ in the communities surrounding the church' and their mission statement was formulated as follows:

In a community devastated by poverty, sickness, broken families and death, we want to bring back true Christian hope, not only through our words but also - following the perfect example of our Lord, Jesus Christ - by reaching out in love to those in need, comforting and supporting them by all means available to us. (SHBC 2013)

In January 2006, the first group of 36 caregivers was trained at Dwaleni. An agreement was made with PSA that they would take responsibility for training the potential caregivers in the following modules:

- volunteering, code of conduct and scope of practice

- situational analysis and needs analysis

- basic nursing care

- palliative and spiritual care

- basic counselling skills

- information and control management on HIV and AIDS and other sexually transmitted infections

- chronic disease management

- communication and networking

- referral system

- record keeping

- nutrition and infection control. 
By the end of that week, 32 members of this group had committed themselves to become volunteer caregivers within their community. Shortly afterwards, the group was registered with the Swaziland Government as a non-profit organisation with the name Shiselweni Reformed HomeBased Care (SHBC). The initial aim was that people who showed characteristic symptoms of AIDS or HIV infection be identified within walking distance of the home of each caregiver. However, it soon transpired that the needs were not limited to taking care of the sick and the dying: running water is non-existent in rural Swaziland and all drinking water needs to be fetched in containers from the nearest stream or fountain. This is a daily task of the women who consider the fetching of water as part of their social interaction with neighbours and friends. The source of their drinking water may be more than a kilometre from their home, but travelling in small groups whilst balancing the container deftly on their heads, becomes a way to catch up on the local news of the community as they share their stories with each other. But when one is too sick to walk, then someone else needs to do this essential task. So the caregivers found increasingly that caring means much more than merely being 'nurses'. It often means fetching firewood, cooking food, sweeping the house, washing the client, changing diapers, being a friend and confidante, or whatever other need is identified.

Caring starts with the building of trust. It is only when a caregiver is trusted, that the client will be willing to speak about their lives. Because of the stigma often associated with HIV and AIDS, confidentiality is of the utmost importance. In one instance, during an interview with one of the clients, when asked what happened when she first announced her HIV status to her family, she responded by saying: 'They laughed at me. They said I'm stupid and why would I tell them, because it's a confidential thing.' Others spoke of the fear and stigma they experienced when they had to inform their family and friends about their HIV status. Of the clients interviewed, 70\% expressed their discomfort when they had to discuss their status with their family members.

However, when asked how they experienced the caregivers, every single client mentioned their appreciation for the way in which the Christian care supporters of SHBC approached them with dignity and also respected the confidential nature of their HIV status, whereas, in their viewpoint, non-Christians would gossip about their clients' status. In the words of one of the clients, to her it 'felt like God loved her even if she was sick'. Another client explained, 'I found myself having a mother because I do not have one. When the care supporter is there, I felt that now I have a mother.' and a third client used almost the same words, 'Even if I am disappointed, she is like my mother. I have no secrets with her. She encourages me and lifts my spirit up.'

A remarkable story was shared by one of the caregivers on what could be accomplished once a trusting relationship had been built:

I went to see my client. She was sick. So I told her to go to the clinic so that they could find out what was wrong with her. Next week, when I returned, she told me that she had been tested and she is HIV-positive. Then she asked me not to tell her husband. 'He mustn't know!' Some weeks later, after finishing my visit to her, her husband was waiting for me a distance from the house. He walked with me until we were out of hearing distance of the home and then told me that he was very worried about himself. He seemed to be sick and he did not get any better. I told him to go to the clinic. Perhaps he had diabetes. So they should draw his blood and try to see what was causing his sickness. When I returned he was waiting for me at the gate. He told me that he had been to the clinic and they had found that he was HIVpositive. But then he asked me not to tell his wife. 'She mustn't know.' And then I brought them together and I helped them to speak to each other and to admit that they were HIV-positive. They were so happy! (in Van Wyngaard 2008b:n.p.)

During another interview, the following story was recorded:

I told the man, 'I have a plan [so you can tell your wife you're HIV positive]'. I knew the husband and wife each was positive, and that the other didn't know. I told him I'd come to their home one Saturday with a slaughtered chicken and ask her to cook it with porridge ... I visited and we all told stories. Then the man said, 'Now, my wife, what if I told you I'm HIV positive?'” She said, 'I would just accept you as you are, because you are still a human being'. I said, 'This is your chance'. So he said, 'I am HIV positive'. She said, 'I'm also positive', and went to get her handbag. 'You see this? I never, ever put it down, because it has my tablets [antiretroviral therapy]'. My heart was so sad, because the man had hidden his tablets under a tree outside the homestead. He dug a hole and everyday he'd go to the tree [to take the ART in secret]. (Root \& Van Wyngaard 2011:2)

\section{Expanding into other communities}

By the end of 2006, people in Swaziland started taking note of this group of care supporters at Dwaleni and requests came from other communities who wished to duplicate this model in their own communities. Initially, it was felt that a second group could be started in February 2007, with a possible third group in the second half of 2007. However, it soon became clear that the need was so great that it would be impossible to restrict the training of new groups to one or two per year. An agreement was therefore made with PSA, not only to continue with the training of new groups as needs were identified, but also to train two of the SHBC caregivers to become trainers of new caregiver groups in the future. Two months after the group of 45 volunteers was trained at Matsanjeni, the third group was trained at Somtongo. By the end of 2007, SHBC had expanded into six different communities.

Presently, the entire SHBC consists of 37 caregiver groups with 1009 volunteers helping more than 3800 clients throughout the Shiselweni district of Swaziland. On average, four new caregiver groups are trained annually, each consisting of approximately 30 caregivers.

\section{International recognition}

Not only Swaziland, but other countries also started taking note of this ministry. In 2008, SHBC was nominated for the 'Courageous Leadership Award', sponsored by World Vision and the Willow Creek Association in Chicago and received 
the runner-up position, despite the participation of churches hundred times the size of the SRC, with budgets running into millions of dollars, in contrast to SHBC which was running at an annual budget of less than R300 000 (\$35 000). Richard Stearns, president of World Vision, gave the following commendation for this prestigious award:

Van Wyngaard's church is located on the frontlines of the pandemic. The devastating effects reach right into his community. As the pastor of a small church, it was hard to know where to start. But the Swaziland Reformed Church focused their AIDS work on training home caregivers. By concentrating their focus on that one area, this small church, with very little financial resources, has been able to have a significant impact in their community and beyond. (Christian News Wire 2008:n.p.)

SHBC has also been identified by Prof. Robin Root, a medical anthropologist and public health researcher at Baruch College, City University of New York, as a 'best practices case study' in a project to explore the high impact potential of faith-based organisations in southern Africa; specifically, to improve and extend the quality of life for people with HIV or AIDS.

In addition, a number of scholarly articles as well as a Masters dissertation have been written about the work of SHBC (cf. Maartens 2012; Root 2011; Root \& Van Wyngaard 2011; Van Wyngaard 2006b; Van Wyngaard 2013).

\section{Evaluation}

Too often, religion is considered to be in opposition to the basic sexual needs of humans. This is also the premise of Thornton (2011) when he says:

Sexual and religious motives seem constantly in conflict. St Augustine makes this clear in his Confessions, a treatise that served as a blueprint for the confessional practices of the Roman Catholic Church, and thus of most of Christianity. (p. 3)

With a pandemic such as HIV and AIDS, which is perceived by many to be the consequence of sinful choices (Brown \& Hendriks 2004:27), it is understandable that the church would often be experienced as judgemental and condemning, not only towards the act of immorality, but also towards those who had committed it. For many then, the church has become a place of 'ungrace' (Yancey 1997:31), incapable of effectively addressing the HIV and AIDS pandemic:

... religion has largely failed in most respects with respect to HIV and AIDS. While it has and continues to motivate people to compassionate action, it is has [sic] failed to provide any moral ground for an ethics of sexuality or a theology of sexuality. This has major consequences since it perverts the efforts of religious people in their compassionately motivated efforts to react to the HIV epidemic, and distorts the nature of compassion itself in response to the human suffering it causes. The theological and ethical projects concerning HIV, AIDS, sexuality and reproduction are failed projects ... Current struggles over the nature of gender, of the role and position of women, of rights to birth/abortion, sexual autonomy and rights, are all impacted by HIV and AIDS. For the most part, the religious response to this has been weak, at best, and destructive at worst. (Thornton 2011:3-4)
It takes a deliberate decision of a church or faith-based organisation to manifest the grace of God to people who have become accustomed to be stigmatised and discriminated against. The interviews conducted with the SHBC clients indicate that their experience of their caregivers is constantly positive, some even comparing their relationship with the caregiver to one as intimate as that between a mother and her daughter. From this research, there is conclusive evidence that a church or faith-based organisation can effectively manifest the grace of God to those with HIV or AIDS if they have a desire to become the hands and feet of Christ to those in need of grace.

\section{Conclusion}

As the stories of the caregivers in Shiselweni are told, the words of Julian the Apostate, quoted earlier, ring true: '... how they love one another!' One of many stories serves as an example of how the care supporters of SHBC demonstrate the grace of God to others:

Today I went out to meet some of the caregivers of one of the home-based caring projects in Swaziland. I travelled along an ugly dirt road, mostly in first gear and carefully negotiating the ditches so as not to damage my car. I had been told that the group of volunteers had been helping someone to build a home. I assumed that it was someone who was too sick to care for himself and for some reason I never really asked about this. The meeting point was at the place where they were busy building the house (not a Western-style house - a small room, perhaps 6 square meters, made of sticks, stones and mud with a thatch roof!). We started speaking and obviously I enquired about the man whose house they were building, assuming that he was lying in bed somewhere and wanting to pay him a visit. To my utmost surprise they told me that the man was at the sjebeen. Now, a sjebeen is nothing other than a bar. I thought I had misheard them: 'Do you want to tell me that you are building this man's house for him and he is at the sjebeen!' 'Yes', they answered. 'He's a drunkard.' I could not believe what I had just heard. 'This is so stupid', I thought. 'Why do you build his home if he's a drunkard?' I asked. 'Because we want him to see that God loves him!' Building a home for a drunkard, because we want him to see that God loves him! Driving back to my home today I could not help saying over and over to myself: 'I was wrong and they are right!'. (Van Wyngaard 2007)

This is indeed a vivid example of manifesting the grace of God to those with HIV or AIDS.

\section{Acknowledgements Competing interests}

The author declares that he has no financial or personal relationships that may have inappropriately influenced him in writing this article.

\section{References}

Brown, J. \& Hendriks, H.J., 2004, 'The AIDS fulcrum: The church in Africa seesawing between alienation, estrangement, prejudice and love', Practical Theology in SA 19(2), 19-36.

Byamugisha, G., Raja, J.J. \& Chitando, E. (eds.), 2012, Is the body of Christ HIV positive? New ecclesiological Christologies in the context of HIV positive communities, New ecclesiolog.
ISPCK, Delhi. 
Campbell, C., Skovdal, M. \& Gibbs, A., 2010, 'Creating social spaces to tackle AIDSrelated stigma: Reviewing the role of church groups in sub-Saharan Africa', AIDS and Behavior 15(6), 1204-1219.

Christian News Wire, 2008, Pennsylvania church tops list recognized for helping people affected by AIDS, viewed 01 May 2013, from http://www.christiannewswire.com/ news/764957498.html

Deacon, H., Stephney, I. \& Prosalendis, S., 2005, Understanding HIV/AIDS stigma: A theoretical and methodological analysis, HSRC, Cape Town.

Esser, H., 1971, 'Grace', in C. Brown (ed.), Dictionary of New Testament theology, vol. 2., pp. 115-124, Paternoster, Exeter.

Genrich, G.L. \& Brader, A.B., 2005, 'Response of religious groups to HIV/AIDS as a sexually transmitted infection in Trinidad', BMC Public Health 5(121), 1-12.

Hermsen, M.A. \& Ten Have, H.A.M.J., 2004, 'Pastoral care, spirituality, and religion in palliative care journals', American Journal of Hospice and Palliative Medicine 21(5), 353-356.

Hlongwana, K. \& Mkhize, S., 2007, 'HIV/AIDS through the lens of Christianity: Perspectives from a South African urban support group', Journal of Social Aspects of HIV/AIDS 4(1), 556-563.

Joint United Nations Programme on HIV and AIDS (UNAIDS), 2005, A report of a theological workshop focusing on HIV- and AIDS-related stigma, UNAIDS, Geneva.

Joint United Nations Programme on HIV and AIDS (UNAIDS), 2010, Swaziland 2010 UNGASS report, UNAIDS, Geneva.

Kidd, R. \& Clay, S., 2003, Understanding and challenging HIV stigma: Toolkit for action, The CHANGE project, Washington, DC.

Louw, J.P. \& Nida, E.A., 1988, Greek-English lexicon, UBS, New York. PMCid:PMC1267932

Maartens, M., 2012, 'Using Shiselweni Reformed Home-Based Care as model for the church's involvement in the community', MDiv dissertation, Dept. of Science of Religion of Missiology, University of Pretoria.

McDonald, H.D., 1980, 'Grace', in M.C. Tenney (ed.), The Zondervan pictorial encyclopedia of the Bible, pp. 799-804, Zondervan, Grand Rapids.

Ministry of Health, 2009, The health sector response to HIV and AIDS plan: 20092014, Government of Swaziland, Mbabane.

Root, R., 2011, 'That's when life changed': Client experiences of church run homebased HIV/AIDS care in Swaziland, viewed 27 August 2012, from http://www. shbcare.org/docs/ChurchRunHBC.HEARD.Root.pdf
Root, R. \& Van Wyngaard, A., 2011, 'Free love: Religion and community home-based care in Swaziland', Global Public Health 6(suppl. 2), 1-18. http://dx.doi.org/10.10 80/17441692.2011.581675

Shiselweni Reformed Home-Based Care (SHBC), 2013, Mission statement, viewed 13 March 2013, from http://www.shbcare.org/index.html

Themistocles, M., 1988, The triumph of the gospel of love, viewed 21 September 2011, from http://www.orthodoxresearchinstitute.org/articles/church_history/ themistocles triumph love.htm

Thornton, R., 2011, 'Sex', 'networks', HIV, and religion: Basic concepts concerning the value of sex and its exchnage in networks, paper presented at the Sexuality, AIDS and Religion conference, Oxford, 28-30 September, viewed 13 January 2012, from http://www.academia.edu/1015747/Sex networks HIV and religion Basic concepts concerning the value of sex and its exchange in networks

Van Klinken, A.S., 2008, “'The body of Christ has AIDS”: A study on the notion of the body of Christ in African theologies responding to HIV and AIDS', Missionalia 36(2/3), 319-336.

Van Wyngaard, A., 2006a, 'Towards a theology of HIV/AIDS', Verbum et Ecclesia 27(1), 265-290. http://dx.doi.org/10.4102/ve.v27i1.148

Van Wyngaard, A., 2006b, 'On becoming the hands and feet of Christ in an AIDS ridden community in Swaziland', Verbum et Ecclesia 27(3), 1095-1109. http:// dx.doi.org/10.4102/ve.v27i3.206

Van Wyngaard, A., 2007, When charity surpasses all human understanding, viewed 21 September 2011, from http://missionissues.wordpress.com/2007/07/26/whencharity-surpasses-all-human-understanding/

Van Wyngaard, A., 2008a, Meeting Jesus over lunch, viewed 27 August 2012, from http://missionissues.wordpress.com/2008/03/19/meeting-jesus-over-lunch/

Van Wyngaard, A., 2008b, Listening to the stories of AIDS workers, viewed 27 August 2012, from http://missionissues.wordpress.com/2008/08/01/listening-to-thestories-of-aids-workers/

Van Wyngaard, A., 2013, 'Addressing the spiritual needs of people infected with and affected by HIV and AIDS in Swaziland', Journal of Social Work in End-of-Life and Palliative Care 9(2\&3), 226-240.

Whiteside, A. \& Whalley, A., 2007, Reviewing 'emergencies' for Swaziland - Shifting the paradigm in a new era, HEARD, Durban.

Yancey, P., 1997, What's so amazing about grace?, Zondervan, Grand Rapids. 